\title{
Standards for proficiencies
}

\section{for instruction librarians and coordinators}

Approved by the ACRL Board, June 24, 2007

Prepared by the ACRL Instruction Section Proficiencies for Instruction Librarians Task Force

\section{Introduction}

As the role of instruction and information literacy continues to grow in the academic library, librarians are faced with a need to develop a more focused set of skills to teach effectively in library instruction programs. At the same time, many libraries struggle to offer meaningful training and professional development to improve instruction, especially without a set of established standards for what makes a good instructor. This document is intended to help instruction librarians de ne and gain the skills needed to be excellent teachers in library instruction programs and to foster collaborations necessary to create and improve information literacy programs.

In many academic libraries, instruction librarians also serve as coordinators of instructional services and as instructional leaders in their organization. In addition to pro ciencies needed for librarians with teaching responsibilities are the skills required for instruction coordinators to manage programs. They also must operate effectively at all levels of the academic organization in order to implement broad-reaching curriculumintegrated information literacy programs.

\section{Application of proficiencies in academic libraries}

The Standards for Pro ciencies for Instruction Librarians and Coordinators allows academic libraries to begin with a common de nition for the scope of responsibilities for instruction librarians and coordinators of instruction programs. At a basic level, they can be used as standards to create professional development opportunities for librarians with teaching responsibilities in order to improve or expand their skills. They can also be used by administrators and coordinators of instructional services to de ne clearly responsibilities of these positions.

For this document, the term instruction librarian refers to any librarian with instruction responsibilities. However, some academic libraries have nonlibrarian professional staff who provide instructional services. These organizations may need to evaluate whether some or all of the pro ciencies are appropriate for all staff who teach. In libraries where the organizational structure is team-based, the role of the instruction coordinator may be shared by multiple team members. In these situations, the instruction team should use the coordinator pro ciencies to allocate areas of responsibility for managing programs and leading initiatives.

Whether identifying responsibilities of librarians who teach or coordinators who manage programs, each organization must decide to implement the pro ciencies in a manner best suited for its own institution. These pro ciencies are designed to $\mathrm{t}$ a wide range of environments. However, emphasizing some criteria over others may be appropriate for individual libraries. The decision to emphasize criteria should be made after assessing the library instruction and information literacy needs of the institution and the current state of the instruction program. Before implementing these pro ciencies, the entire library instruction staff should be consulted and given an opportunity to provide input. Rather than serving as in exible criteria for evaluating instruction librarians and coordinators, these pro ciencies will assist the librarians to improve instruction and programs. For example, 
they could be used to guide peer evaluations in order to provide librarians with constructive feedback. Or librarians could decide to assess their pro ciency in one or more categories over multiple classes in a semester.

In conjunction with other ACRL documents, including the ACRL Information Literacy Competency Standards for Higher Education and the ACRL Instruction Section s Guidelines for Instruction Programs in Academic Libraries, the Standards for Pro ciencies for Instruction Librarians and Coordinators should be a basis for broader library discussions regarding the staf ng and skills necessary to create library instruction and information literacy programs that meet curricular demands.

\section{Organization of the proficiencies}

The pro ciencies are organized alphabetically into the following 12 categories: administrative skills, assessment and evaluation skills, communication skills, curriculum knowledge, information literacy integration skills, instructional design skills, leadership skills, planning skills, presentation skills, promotion skills, subject expertise, teaching skills.

Each category contains core skills for instruction librarians and many categories contain additional skills for instruction coordinators. The standards de ne 41 core pro ciencies for instruction librarians and 28 additional pro ciencies for instruction coordinators.

\section{Proficiencies for Instruction Librarians}

1. Administrative skills

The effective instruction librarian:

1.1. Communicates own instruction activities and goals with the instruction coordinator on a regular basis to ensure alignment with desired learning outcomes and goals and objectives of the overall instruction program.

\section{About the standards}

The ACRL Instruction Section (IS) Pro ciencies for Instruction Librarians Task Force was formed in December 2004 and given the charge:

To develop a list of pro ciencies required of instruction librarians and other librarians who contribute to instructional services and programs at their institutions, focusing on broad areas of proficiency rather than a comprehensive list of skills; consider similar documents such as RUSA s Professional Competencies for Reference and User Services Librarians ; outline an approach to assist individuals and organizations in selecting the pro ciencies most appropriate for their environment; design the document in a manner that would lend itself to publication as an ACRL standard or guideline; and provide the IS Executive Committee with a nal document and recommendations for dissemination prior to the 2005 Annual Conference.

The Pro ciencies for Instruction Librarians Task Force was designated as a virtual task force, and all of its work was conducted using online communication technologies. The task force started its work based on the results reported in the 1999 nal report from the ACRL IS Skill Areas for Instruction Librarians Task Force.

After reviewing the literature (see resources consulted at the end of document), the Pro ciencies for Instruction Librarians Task Force identi ed broad categories and then speci c pro ciencies that comprise an instruction librarian s areas of responsibility. While some institutions have designated instruction librarians, the task force de ned the pro ciencies to be appropriate for any librarian with instruction responsibilities. Since the size of institution may affect the scope of librarians instruction responsibilities, pro ciencies are included that are applicable to librarians in all types of academic environments. Pro ciencies in this document received approval from a majority of the task force members. The task force solicited comments from the instruction community through electronic discussion groups and the IS Web site, and revised this document based on the feedback received. ACRL IS Pro ciencies for Instruction Librarians Task Force, 2005-2006: Clara Fowler (Chair), Carla Wilson Buss, Chad M. Kahl, and Susan Vega Garcia. 
1.2. Works well in a team environment and provides team with knowledge, skill, and time to improve instructional services.

1.3. Maintains and regularly reports accurate statistics and other records re ecting own instruction activities.

The effective coordinator of instruction:

1.4. Ensures that all library instructors are aware of the desired learning outcomes and goals and objectives of the overall instruction program.

1.5. Recognizes and uses the skills of other librarians and teaching staff, assigns classes and related tasks, when relevant, to those best suited for the objectives of the class.

1.6. Represents the instructional program in the strategic planning process.

1.7. Documents the activities, effectiveness, and needs of the instruction program through statistical analysis, formal reports, presentations, and data analysis.

1.8. Helps create teaching environments that support the needs of the instruction program.

\section{Assessment and evaluation skills}

The effective instruction librarian:

2.1 Designs effective assessments of student learning and uses the data collected to guide personal teaching and professional development.

The effective coordinator of instruction:

2.2 Develops and implements iterative peer instructor assessment models in order to provide constructive feedback to librarians on teaching effectiveness. Stresses commitment to improving teaching, rather than exclusively evaluating job performance.

2.3 Assists librarians to develop programmatic assessment models that measure the incremental development of information literacy skills throughout a student s matriculation.

2.4 Identifies and analyzes factors that measure the impact of library instruction programs on library services, campus programs, academic departments, and student learning.

2.5 Identi es national, regional, state, local, and institution assessment and evaluation ef- forts and works with instruction librarians to connect them with the librarys instructional efforts.

\section{Communication skills}

The effective instruction librarian:

3.1. Maintains awareness of communication needs of different learning styles, and adjusts own communication style and methods accordingly.

3.2. Leads or facilitates discussion of controversial or unexpected issues in a skillful, non-judgmental manner that helps students to learn.

3.3. Uses common communication technologies to provide assistance to students in and outside the classroom.

3.4. Requests feedback from peers on instruction-related communication skills and uses it for self improvement.

\section{Curriculum knowledge}

The effective instruction librarian:

4.1. Analyzes the curriculum in assigned subject area(s) to identify courses and programs appropriate for instruction.

4.2. Keeps aware of student assignments and the role of the library in completing these assignments.

The effective coordinator of instruction:

4.3. Identi es and communicates regularly with those responsible for curriculum decisions at the institution, college, or department level.

\section{Information literacy integration} skills

The effective instruction librarian:

5.1. Describes the role of information literacy in academia and the patrons, programs, and departments they serve.

5.2. Collaborates with classroom faculty to integrate appropriate information literacy competencies, concepts, and skills into library instruction sessions, assignments, and course content.

5.3. Communicates with classroom faculty and administrators to collaboratively plan and 
implement the incremental integration of information literacy competencies and concepts within a subject discipline curriculum.

The effective coordinator of instruction:

5.4. Investigates aligning information literacy standards with the institution s program review, departmental learning objectives, and/or accreditation standards.

5.5. Collaborates with institution-wide faculty development programs to support ongoing faculty training.

5.6. Encourages, guides, and supports instruction librarians to collaborate with classroom faculty and administrators in the development of increased focus on information literacy whether at the course, program, department, or campus-wide level.

\section{Instructional design skills}

The effective instruction librarian:

6.1. Collaborates with classroom faculty by de ning expectations and desired learning outcomes in order to determine appropriate information literacy pro ciencies and resources to be introduced in library instruction.

6.2. Sequences information in a lesson plan to guide the instruction session, course, workshop, or other instructional material.

6.3. Creates learner-centered course content and incorporates activities directly tied to learning outcomes.

6.4. Assists learners to assess their own information needs, differentiate among sources of information and help them to develop skills to effectively identify, locate, and evaluate sources.

6.5. Scales presentation content to the amount of time and space available.

6.6. Designs instruction to best meet the common learning characteristics of learners, including prior knowledge and experience, motivation to learn, cognitive abilities, and circumstances under which they will be learning.

6.7. Integrates appropriate technology into instruction to support experiential and collaborative learning as well as to improve student receptiveness, comprehension, and retention of information.
The effective coordinator of instruction:

6.8 Identi es, encourages, and supports training opportunities for librarians in instructional design and incorporating technology to support pedagogy.

\section{Leadership skills}

The effective instruction librarian:

7.1. Demonstrates initiative by actively seeking out instruction opportunities or instruction committee work within the library, at the institution, and in regional or national organizations.

7.2. Encourages librarians and classroom faculty to participate in discussions, ask questions, and to share ideas regarding instruction.

The effective coordinator of instruction:

7.3. Mentors librarians and provides constructive feedback to improve instruction.

7.4. Works effectively with the head of the library and other supervisors to promote and develop library instruction on campus.

7.5. Seeks leadership roles within the library and institution that promote library instruction initiatives.

7.6. Advocates for improving instructional services through support for training or improving skills of instruction librarians, better facilities, increased emphasis on library instruction by library administration, and dedication of resources to these areas.

\section{Planning skills}

The effective instruction librarian:

8.1. Plans presentation content and delivery in advance, and manages preparation time for instruction.

The effective coordinator of instruction:

8.2. Seeks potential partners to create new instruction opportunities.

8.3. Anticipates growth and change when planning instructional services, and adapts plans to these changes.

8.4. Links instructional services to the mission of the institution and other campus planning documents and relevant off-campus documents (e.g., national standards, key publications, and reports). 
8.5. Leads instructional staff in creating shortand long-term goals and objectives in order to continuously develop and improve instruction programs.

\section{Presentation skills}

The effective instruction librarian:

9.1. Makes the best possible use of voice, eye contact, and gestures to keep class lively and students engaged.

9.2. Presents instructional content in diverse ways (written, oral, visual, online, or using presentation software) and selects appropriate delivery methods according to class needs.

9.3. Uses classroom instructional technologies and makes smooth transitions between technological tools.

9.4. Seeks to clarify confusing terminology, avoids excessive jargon, and uses vocabulary appropriate for level of students.

9.5. Practices or re nes instruction content as necessary in order to achieve familiarity and con dence with planned presentation.

The effective coordinator of instruction:

9.6. Encourages librarians to experiment and take risks, to try new approaches and technologies, and to share experiences and materials.

\section{Promotion skills}

The effective instruction librarian:

10.1. Promotes library instruction opportunities and services to new faculty, underserved departments and programs, and elsewhere on campus, as relevant to instruction responsibilities and subject areas served.

10.2. Establishes and maintains a working relationship with assigned academic departments and programs in order to incorporate library instruction into the curriculum and other educational initiatives.

10.3. Represents the library and the instruction program in an effective and positive manner at local, regional, and national meetings and conferences

The effective coordinator of instruction:

10.4. Identi es relevant existing events, lobbies to be included in those events, and cre- ates new special events promoting the library instruction program.

10.5. Collaborates with graphic designers and Web editors to create effective promotional materials for the print and Web environments.

10.6. Establishes and maintains a working relationship with various campus-wide publications in order to promote the library and the instruction program.

10.7. Identi es and creates training opportunities for librarians in marketing and outreach basics to enable more effective collaboration with classroom faculty.

\section{Subject expertise}

The effective instruction librarian:

11.1. Keeps current with basic precepts, theories, methodologies, and topics in assigned and related subject areas and incorporates those ideas, as relevant, when planning instruction.

11.2. Identi es core primary and secondary sources within a subject area or related disciplines and promotes the use of those resources through instruction.

11.3. Uses the vocabulary for the subject and related disciplines in the classroom and when working with departmental faculty and students.

\section{Teaching skills}

The effective instruction librarian:

12.1 Creates a learner-centered teaching environment by using active, collaborative, and other appropriate learning activities.

12.2 Modi es teaching methods and delivery to address different learning styles, language abilities, developmental skills, age groups, and the diverse needs of student learners.

12.3 Participates in constructive studentteacher exchanges by encouraging students to ask and answer questions by allowing adequate time, rephrasing questions, and asking probing or engaging questions.

12.4 Modi es teaching methods to match the class style and setting.

12.5 Encourages teaching faculty during the class to participate in discussions, to link library instruction content to course content, and to answer student questions. 
12.6 Re ects on practice in order to improve teaching skills and acquires new knowledge of teaching methods and learning theories.

12.7 Shares teaching skills and knowledge with other instructional staff.

\section{Resources Consulted by Task Force}

Barrett, Jill. 1997. A Competency Framework for Effective Teaching. Perth, W.A: Murdoch University.

Botts, Carroll, and Mark Emmons. 2002. Developing teaching competencies for instructors in the academic library: A case study. Public Services Quarterly 1 (3):65-81.

Cennamo, Katherine, and Eugene Kalk. 2005. Real World Instructional Design. Canada: Wadsworth.

Competencies for Information Professionals of the 21st Century 2006. (Revised). Special Libraries Association, June 2003 [cited Feb. 28 2006]. Available at www.sla.org/content/learn/ comp2003/index.cfm.

Core and Advanced Competencies for $\mathrm{Li}$ brary Instructors \& Coordinators. 1985. ACRL Instruction Section.

ECAR Study of Students and Information Technology, 2005: Convenience, Connection, Control, and Learning. EDUCAUSE Center for Applied Research 2005 [cited February 28, 2006]. Available at www.educause.edu/ ers0506.

Fowler, Clara, and Scott Walter. 2003. Instructional Leadership. CERL News 64 (7):465-468.

Fyffe, Richard, and Scott Walter. 2005. Building a New Future: Preparing Future Faculty and Responsible Conduct of Research Programs as a Venue for Scholarly Communication. CERL News 66 (9):654- 663.

Gagne, Robert, and Karen Medsker. 1996. The Conditions of Learning: Training Applications. Fort Worth: Harcourt Brace College Pub.

Kember, David, and Kam-Por Kwan. 2000. Lecturers Approaches to Teaching and Their Relationship to Conceptions of Good Teaching. Instructional Science 28 (5):469-490.

Peacock, Judith. 2001. Teaching Skills for Teaching Librarians: Postcards from the Edge of the Educational Paradigm. Australian Academic \& Research Libraries 32 (1):26-42.

Ramsden, Paul. 2003. Learning to Teach in Higher Education. 2nd ed. New York: RoutledgeFalmer.

Rockman, Ilene. 2004. Integrating Information Literacy in the Higher Education Curriculum. San Francisco: Jossey-Bass.

Samuelowicz, Katherine, and John Bain. 2001. Revisiting Academics Beliefs about Teaching and Learning. Higher Education 41:299-325.

Shonrock, Diana, and Craig Mulder. 1993. Instruction Librarians: Acquiring the Pro ciencies Critical to Their Work. College E Research Libraries 54:137-149.

Students' Information Literacy Needs in the 21st Century: Competencies for TeacherLibrarians 2006. Canadian Association for School Libraries 1997 [cited February 28 2006]. Available at www.caslibraries.ca/publications /pub_literacy.aspx.

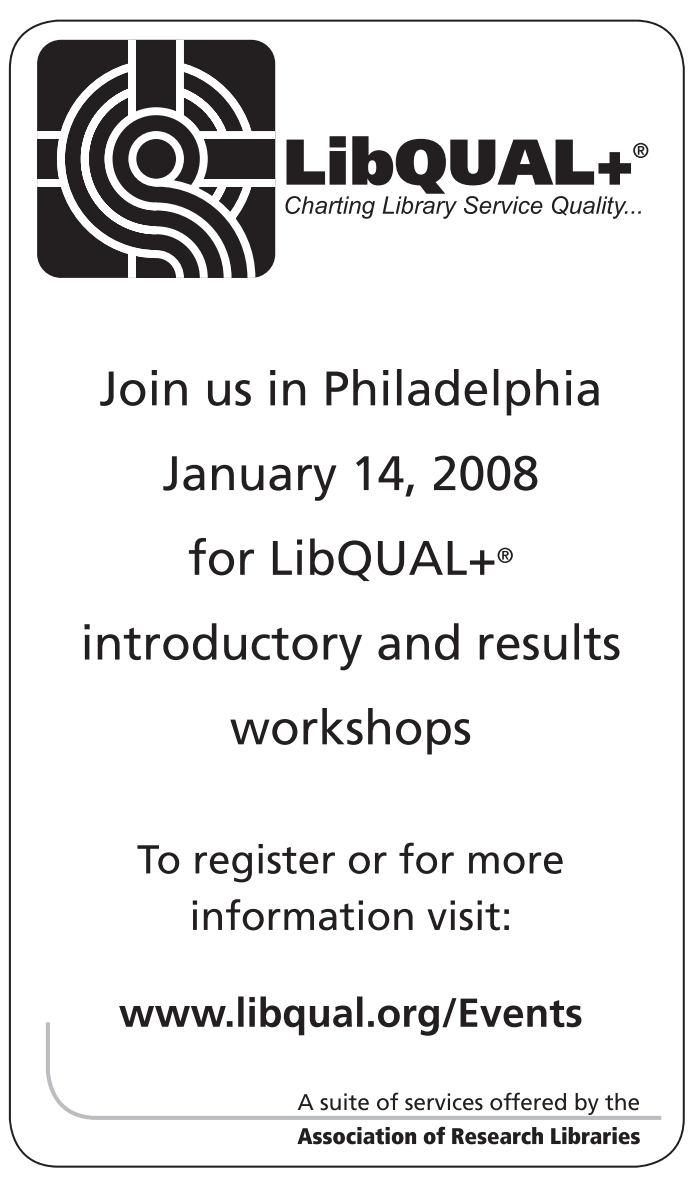

